\title{
ANALISIS FAKTOR PENYEBAB KETERLAMBATAN DI PROYEK SUPERBLOCK ASC DENGAN PROGRAM @RISK
}

\author{
Kevin Setiawan ${ }^{1}$ dan Oei Fuk Jin $^{2}$ \\ ${ }^{1}$ Program Studi Sarjana Teknik Sipil, Universitas Tarumanagara, Jl. Letjen S. Parman No.1 Jakarta \\ Email : Kevinz_S@yahoo.com \\ ${ }^{2}$ Program Studi Sarjana Teknik Sipil, Universitas Tarumanagara, Jl. Letjen S. Parman No.1 Jakarta \\ Email:Fukjin.untar.@gmail.com
}

\begin{abstract}
ABSTRAK
Terdapat beberapa faktor risiko yang berpengaruh pada keterlambatan suatu proyek dan faktor-faktor risiko ini sangat penting untuk diketahui. Penelitian ini bertujuan untuk mengetahui faktor-faktor risiko yang ada di proyek ASC berikut penyebabnya. Data penelitian ini diperoleh dengan penyebaran kuesioner untuk mendapatkan frekuensi dan dampak keterlambatan. Program @RISK digunakan untuk membantu peringkat faktor risiko yang ada. Sementara itu, wawancara terhadap 5 site manager yang ada dilakukan untuk melakukan validasi dari penelitian ini. Dari hasil analisis, diperoleh 10 faktor risiko yang signifikan mempengaruhi keterlambatan proyek, diantaranya adalah : terjadi perubahan desain dari pihak Owner, pendetailan gambar yang tidak sesuai dengan kondisi lapangan, cuaca yang berpengaruh pada aktifitas konstruksi, ketidaktepatan waktu pemesanan material, kerusakan peralatan saat dibutuhkan, kekurangan alat saat dibutuhkan, terjadi perubahan jadwal \& biaya rencana dari pihak Owner, masalah longsoran saat galian tanah, kerusakan struktur pada kolom beton dan adanya retak struktur pada retaining wall.
\end{abstract}

Kata Kunci : Indeks Risiko, Program @RISK, Keterlambatan Proyek

\section{PENDAHULUAN}

Proyek superblock high rise-building dapat dikatakan sebagai proyek yang berisiko tinggi mengingat besarnya bobot pekerjaan dan tingginya struktur bangunan yang akan dibangun. Proses konstruksi pada proyek ini biasanya memakan waktu yang lama dan tingkat kesulitan yang rumit sehingga dapat memunculkan berbagai macam risiko. Dalam pelaksanaan proyek konstruksi gedung yang berskala besar seperti proyek superblock atau proyek mixed used, terdapat perbedaan faktor-faktor risiko penyebab keterlambatan yang dominan dari beberapa tower yang dikerjakan masing-masing site manager. Adanya perbedaan faktor-faktor risiko yang terjadi pada beberapa tower dalam 1 lokasi proyek yang sama ini menjadi bahan penelitian skripsi yang berjudul "Analisis Faktor Penyebab Keterlambatan yang Terjadi di Proyek Superblock ASC dengan program @RISK”.

\section{TUJUAN PENELITIAN}

Mengetahui faktor risiko penyebab keterlambatan yang harus ditangani dan faktor risiko penyebab keterlambatan yang bisa diabaikan, mengetahui peringkat faktor risiko penyebab keterlambatan yang terjadi dari masing-masing site manager dalam 1 lokasi proyek yang sama, serta mengetahui penyebab-penyebab utama dari keterlambatan proyek yang terjadi.

\section{BATASAN MASALAH}

Penelitian difokuskan pada pekerjaan galian tanah dan pekerjaan struktur tower dan podium serta penelitian dilakukan pada Proyek Pembangunan superblock ASC di Kelapa Gading, Jakarta Utara. 


\section{METODOLOGI PENELITIAN}

Untuk mencapai maksud \& tujuan penelitian skripsi ini, dilakukan beberapa tahapan penelitian skripsi yang dapat dilihat pada diagram alur penelitian (flowchart) ini.

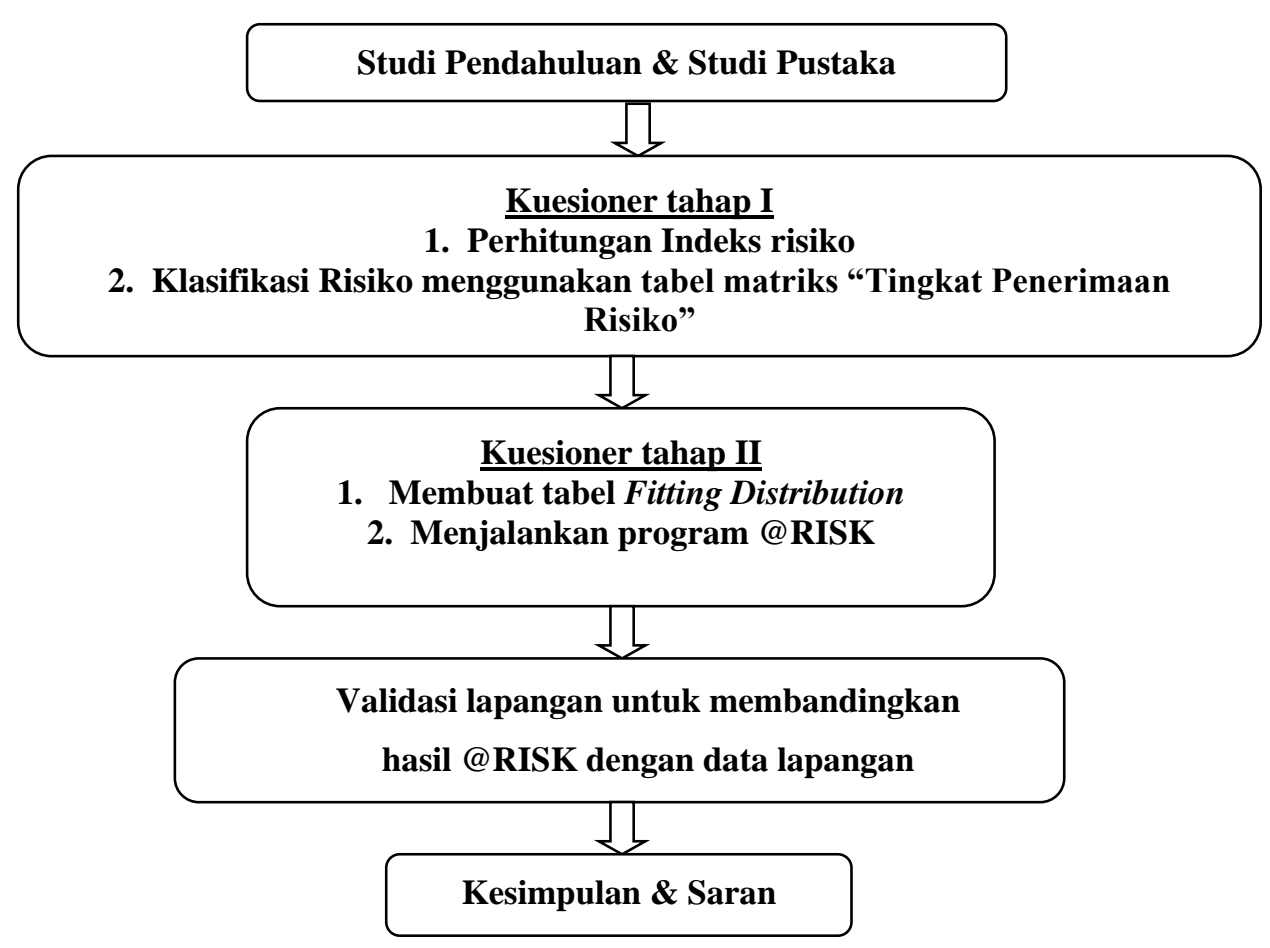

\section{HASIL DAN PEMBAHASAN}

Dari hasil studi literatur yang dilakukan maka ditemukan 32 variabel faktor risiko yang dapat menyebabkan keterlambatan pada proyek konstruksi superblock ASC seperti yang disajikan pada tabel 1 di bawah ini:

\section{Responden Penelitian}

Responden yang disertakan dalam penelitian ini adalah Site manager dari perusahaan kontraktor PT.TOEP. Di proyek konstruksi ASC ini terdapat 5 site manager yang terdiri dari 3 site manager di tower 1, tower 2, tower 3 dan 2 site manager di podium zona 4 , zona 5 , zona 6 dan zona 7 . 
Tabel 1 Variabel Faktor Risiko Penyebab Keterlambatan dalam Proyek

\begin{tabular}{|c|c|c|}
\hline No. & Variabel & Sumber \\
\hline 1 & $\begin{array}{c}\text { Keterlambatan } \\
\text { pengiriman peralatan \& } \\
\text { material } \\
\end{array}$ & $\begin{array}{c}\text { Subiyanto (2010), } \\
\text { Soeharto (2011) }\end{array}$ \\
\hline 2 & $\begin{array}{l}\text { Kerusakan material di } \\
\text { tempat penyimpanan }\end{array}$ & Soeharto (2011) \\
\hline 3 & $\begin{array}{c}\text { Ketidaktepatan waktu } \\
\text { pemesanan peralatan \& } \\
\text { material }\end{array}$ & $\begin{array}{l}\text { I. Enshassi (2003), } \\
\text { Kaming (1997) }\end{array}$ \\
\hline 4 & $\begin{array}{c}\text { Kerusakan Peralatan saat } \\
\text { pekerjaan struktur }\end{array}$ & $\begin{array}{l}\text { Reftery, J. (1994), } \\
\text { Chan and } \\
\text { Kumaraswamy (2002) }\end{array}$ \\
\hline 5 & $\begin{array}{l}\text { Kekurangan Peralatan } \\
\text { yang dibutuhkan }\end{array}$ & $\begin{array}{c}\text { Reftery, J. (1994), } \\
\text { Chan and } \\
\text { Kumaraswamy (2002) }\end{array}$ \\
\hline 6 & $\begin{array}{c}\text { Produktivitas Peralatan } \\
\text { dan alat berat yang } \\
\text { rendah } \\
\end{array}$ & $\begin{array}{l}\text { Reftery, J. (1994), } \\
\text { Subiyanto (2010) } \\
\end{array}$ \\
\hline 7 & $\begin{array}{l}\text { Pengaruh cuaca pada } \\
\text { aktifitas konstruksi. }\end{array}$ & $\begin{array}{l}\text { Asiyanto (2008), I. } \\
\text { Enshassi (2003) }\end{array}$ \\
\hline 8 & $\begin{array}{l}\text { Masalah longsoran tanah } \\
\text { pada proses galian tanah }\end{array}$ & Subiyanto (2010) \\
\hline 9 & $\begin{array}{c}\text { Kekurangan Tenaga } \\
\text { Kerja pada pekerjaan } \\
\text { struktur }\end{array}$ & $\begin{array}{c}\text { Chan and } \\
\text { Kumaraswamy } \\
\text { (2002), Kaming et al. } \\
\text { (1997) }\end{array}$ \\
\hline 10 & $\begin{array}{c}\text { Adanya retak struktur } \\
\text { pada struktur Retaining } \\
\text { Wall }\end{array}$ & $\begin{array}{c}\text { Chan and } \\
\text { Kumaraswamy(2002) }\end{array}$ \\
\hline 11 & $\begin{array}{l}\text { Pendetailan Gambar dari } \\
\text { Divisi Engineering yang } \\
\text { tidak sesuai dengan } \\
\text { kondisi lapangan } \\
\end{array}$ & $\begin{array}{c}\text { Chan and } \\
\text { Kumaraswamy(2002) }\end{array}$ \\
\hline 12 & $\begin{array}{c}\text { Terjadinya perubahan } \\
\text { desain dari pihak Owner }\end{array}$ & Kaming et al. (1997) \\
\hline 13 & $\begin{array}{l}\text { Kesalahan penggunaan } \\
\text { material sehingga ada } \\
\text { yang terbuang }\end{array}$ & $\begin{array}{c}\text { Sentosa Imanuel dan } \\
\text { Harry P Chandra } \\
(2012)\end{array}$ \\
\hline 14 & $\begin{array}{c}\text { Gempa bumi } \\
\text { menyebabkan kerusakan } \\
\text { struktural }\end{array}$ & $\begin{array}{l}\text { Subiyanto (2010), } \\
\text { Kaming et al. (1997) }\end{array}$ \\
\hline 15 & $\begin{array}{c}\text { Operator peralatan yang } \\
\text { masih kurang } \\
\text { berpengalaman }\end{array}$ & $\begin{array}{c}\text { Chan and } \\
\text { Kumaraswamy } \\
\text { (2002), Subiyanto } \\
\text { (2010) } \\
\end{array}$ \\
\hline 16 & Kurang koordinasi & $\begin{array}{c}\text { Chan and } \\
\text { Kumaraswamy } \\
\text { (2002), Subiyanto } \\
\text { (2010) }\end{array}$ \\
\hline
\end{tabular}

\begin{tabular}{|c|c|c|}
\hline No. & Variabel & Sumber \\
\hline 17 & $\begin{array}{l}\text { Kekurangan pekerja } \\
\text { yang professional }\end{array}$ & $\begin{array}{l}\text { I. Enshassi (2003), } \\
\text { Subiyanto (2010), }\end{array}$ \\
\hline 18 & $\begin{array}{l}\text { Terjadi perubahan jadwal } \\
\& \text { biaya rencana dari } \\
\text { pihak Owner }\end{array}$ & $\begin{array}{c}\text { Chan and } \\
\text { Kumaraswamy } \\
\text { (2002), Soeharto } \\
\text { (2011) }\end{array}$ \\
\hline 19 & $\begin{array}{c}\text { Adanya instrusi air dari } \\
\text { di dekat proyek }\end{array}$ & $\begin{array}{c}\text { Subiyanto(2010), } \\
\text { Chan } \\
\text { andKumaraswamy } \\
\text { (2002) }\end{array}$ \\
\hline 20 & $\begin{array}{c}\text { Volume Pengiriman } \\
\text { tidak tepat }\end{array}$ & $\begin{array}{l}\text { Soeharto (2011), } \\
\text { Soemarno (2008) }\end{array}$ \\
\hline 21 & $\begin{array}{l}\text { Produktivitas tenaga } \\
\text { kerja yang rendah }\end{array}$ & $\begin{array}{c}\text { Chan and } \\
\text { Kumaraswamy } \\
\text { (2002), Soemarno } \\
\text { (2008) }\end{array}$ \\
\hline 22 & $\begin{array}{c}\text { Kerusakan pada struktur } \\
\text { pelat beton }\end{array}$ & $\begin{array}{c}\text { Chan and } \\
\text { Kumaraswamy (2002) }\end{array}$ \\
\hline 23 & $\begin{array}{c}\text { Kerusakan pada struktur } \\
\text { balok beton }\end{array}$ & Asiyanto (2008) \\
\hline 24 & $\begin{array}{c}\text { Kerusakan pada struktur } \\
\text { kolom beton }\end{array}$ & Asiyanto (2008) \\
\hline 25 & $\begin{array}{c}\text { Waktu pelepasan } \\
\text { bekisting tidak tepat }\end{array}$ & Asiyanto (2008) \\
\hline 26 & $\begin{array}{c}\text { Kesalahan menuangkan } \\
\text { beton sehingga timbul } \\
\text { segregasi material }\end{array}$ & $\begin{array}{c}\text { Chan and } \\
\text { Kumaraswamy } \\
\text { (2002), I. Enshassi } \\
\text { (2003) }\end{array}$ \\
\hline 27 & $\begin{array}{c}\text { Jumlah dan mutu baja } \\
\text { tidak sesuai spesifikasi } \\
\text { teknis }\end{array}$ & $\begin{array}{c}\text { Chan and } \\
\text { Kumaraswamy } \\
\text { (2002), Asiyanto } \\
\text { (2008) }\end{array}$ \\
\hline 28 & $\begin{array}{l}\text { Jumlah dan mutu beton } \\
\text { tidak sesuai rencana }\end{array}$ & $\begin{array}{c}\text { Chan and } \\
\text { Kumaraswamy } \\
\text { (2002), Asiyanto } \\
\text { (2008) }\end{array}$ \\
\hline 29 & $\begin{array}{c}\text { Kesalahan merangkai } \\
\text { tulangan tumpuan \& } \\
\text { lapangan }\end{array}$ & $\begin{array}{c}\text { Chan and } \\
\text { Kumaraswamy } \\
(2002), \\
\text { Asiyanto(2008) }\end{array}$ \\
\hline 30 & $\begin{array}{c}\text { Sambungan tulangan } \\
\text { antar balok-kolom dan } \\
\text { antar kolom-kolom tidak } \\
\text { benar }\end{array}$ & $\begin{array}{c}\text { Chan and } \\
\text { Kumaraswamy }(2002)\end{array}$ \\
\hline 31 & $\begin{array}{c}\text { Kesalahan merakit } \\
\text { bekisting sehingga cor } \\
\text { beton bocor }\end{array}$ & Asiyanto (2008) \\
\hline 32 & $\begin{array}{c}\text { Tidak terjadwalnya } \\
\text { pemindahan tenaga kerja } \\
\text { ke pekerjaan lain }\end{array}$ & $\begin{array}{c}\text { Chan and } \\
\text { Kumaraswamy(2002), } \\
\text { Soeharto (2011) }\end{array}$ \\
\hline
\end{tabular}




\section{Kuesioner Tahap I}

Setelah dilakukan penyebaran kuesioner terhadap 5 Site manager, maka dilakukan rekapitulasi ulang data kedalam lembar kerja Microsoft Excel. Dalam setiap faktor risiko yang diidentifikasi diperkirakan tingkat probabilitas kemungkinan terjadinya dengan skala nilai sebagai berikut:

Tabel 2 Tabel Skala Frekuensi (Likehoodz) Tahap I

\begin{tabular}{|c|l|l|c|}
\hline Skala & \multicolumn{1}{|c|}{ Tingkat Frekuensi } & \multicolumn{1}{c|}{ Keterangan } & $\begin{array}{c}\% \\
\text { Kemungkinan }\end{array}$ \\
\hline $\mathbf{5}$ & $\begin{array}{l}\text { Sangat Sering (Almost } \\
\text { Certain) }\end{array}$ & Selalu terjadi pada setiap kondisi & $>50 \%$ \\
\hline $\mathbf{4}$ & Sering (Probable) & Sekali setiap 4 proyek & \multicolumn{2}{c|}{$25 \%-50$} \\
\hline $\mathbf{3}$ & Kadang-kadang (Occasional) & Sekali setiap 10 proyek & \multicolumn{2}{c|}{ \% } \\
\hline $\mathbf{2}$ & Jarang (Unlikely) & Sekali setiap 20 proyek & \multicolumn{2}{|c|}{$<$} \\
\hline $\mathbf{1}$ & Sangat Jarang (Rare) & $\begin{array}{l}\text { Kurang dari sekali setiap 20 } \\
\text { proyek }\end{array}$ & \multicolumn{2}{|c|}{} \\
\hline
\end{tabular}

Sumber : Godfrey (1996), Saputra (2005)

Disetiap dampak yang ada, dinilai berdasarkan dampak yang ditimbulkan dari risiko tersebut dengan skala nilai sebagai berikut:

Tabel 4 Tabel Skala Dampak (consequence) Tahap I

\begin{tabular}{|c|l|c|}
\hline Skala & \multicolumn{1}{|c|}{ Tingkat Dampak } & $\begin{array}{c}\text { Keterangan } \\
\text { (Keterlambatan/Schedule Slip) }\end{array}$ \\
\hline $\mathbf{5}$ & Sangat Besar (Catastropic) & $>20 \%$ \\
\hline $\mathbf{4}$ & Besar (Critical) & $10 \%-20 \%$ \\
\hline $\mathbf{3}$ & Sedang (Moderate) & $5 \%-10 \%$ \\
\hline $\mathbf{2}$ & Kecil (Low) & $<5 \%$ \\
\hline $\mathbf{1}$ & Sangat Kecil (Negligible) & Schedule slip tidak signifikan \\
\hline \multicolumn{2}{|c|}{ Sumber: Supriyono (2004), PMBOK-Guide, 2008 Edition, p.189 } \\
\hline
\end{tabular}

Setelah semua data dari masing-masing site manager ditabulasi kedalam tabel di Micrososft Excel, dilakukan perhitungan indeks risiko. Indeks risiko didapat dari hasil perkalian frekuensi dan dampak yang kemudian dibandingkan dengan matriks tingkat penerimaan risiko yang dapat dilihat pada gambar 4.2. Sedangkan frekuensi dan dampak yang digunakan dalam perkalian tersebut adalah nilai rata-rata frekuensi dan nilai rata-rata dampak dari hasil survey yang telah dilakukan dengan rumus sebagai berikut ini :

1. Frekuensi rata-rata $(\overline{\mathrm{F}})=\frac{\text { total frekuensi }}{\text { jumlah responden }}$

2. Dampak rata-rata $(\bar{D})=\frac{\text { total dampak }}{\text { jumlah responden }}$.

Berikut ini adalah matriks tingkat penerimaan risiko yang digunakan untuk klasifikasi risiko : 

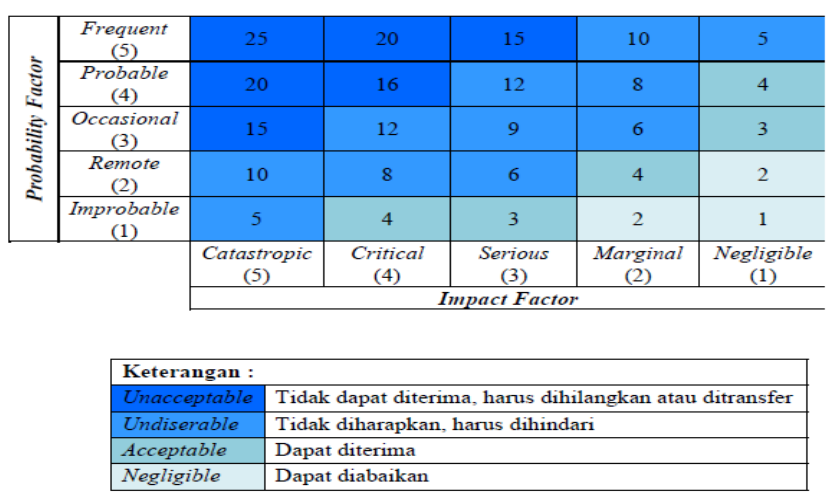

Gambar 1 Matriks Tingkat Penerimaan Risiko (Assesment of Risk Acceptability)

Sumber : Godfrey (1996),Saputra (2005)

Dari tabel indeks risiko diatas, dapat dilihat bahwa dari 32 variabel risiko yang ada, ternyata terdapat 8 variabel risiko keterlambatan yang bersifat Undiserable (tidak diharapkan), 2 variabel risiko yang bersifat Unacceptable ( tidak dapat diterima), 15 variabel risiko yang bersifat negligible (dapat diabaikan) dan 7 variabel risiko yang bersifat acceptable (dapat diterima). Sesuai dengan tujuan dari analisis risiko, variabel-variabel risiko yang termasuk dalam kategori Undiserable (tidak diharapkan) dan Unacceptable ( tidak dapat diterima) disebut sebagai risiko yang dominan dan harus dicari solusinya. Adapun faktor risiko penyebab keterlambatan dominan sebagai berikut ini :

Tabel 6 Variabel Faktor Risiko Penyebab Keterlambatan Dominan

\begin{tabular}{|c|c|}
\hline No. & Faktor Risiko \\
\hline 1 & $\begin{array}{c}\text { Ketidaktepatan waktu } \\
\text { pemesanan peralatan \& } \\
\text { material }\end{array}$ \\
\hline 2 & $\begin{array}{c}\text { Kerusakan Peralatan saat } \\
\text { dibutuhkan }\end{array}$ \\
\hline 3 & $\begin{array}{c}\text { Kekurangan Peralatan yang } \\
\text { dibutuhkan }\end{array}$ \\
\hline 4 & $\begin{array}{c}\text { Pengaruh cuaca pada aktifitas } \\
\text { konstruksi. }\end{array}$ \\
\hline 5 & $\begin{array}{c}\text { Masalah longsoran tanah pada } \\
\text { proses galian tanah }\end{array}$ \\
\hline
\end{tabular}

\begin{tabular}{|c|c|}
\hline No. & Faktor Risiko \\
\hline 6 & $\begin{array}{c}\text { Adanya retak struktur pada } \\
\text { Retaining Wall }\end{array}$ \\
\hline 7 & $\begin{array}{c}\text { Pendetailan gambar dari Divisi } \\
\text { Engineering yang tidak sesuai } \\
\text { dengan kondisi lapangan }\end{array}$ \\
\hline 8 & $\begin{array}{c}\text { Terjadinya perubahan desain } \\
\text { dari pihak } \text { owner }\end{array}$ \\
\hline 9 & $\begin{array}{c}\text { Terjadi perubahan jadwal \& } \\
\text { biaya rencana dari pihak } \text { owner }\end{array}$ \\
\hline 10 & $\begin{array}{c}\text { Kerusakan pada struktur } \\
\text { kolom beton. }\end{array}$ \\
\hline
\end{tabular}

\section{Kuesioner Tahap Kedua}

Setelah diperoleh 10 faktor risiko yang bersifat Unacceptable dan Undiserable dari hasil perhitungan indeks risiko dan klasifikasi risiko, maka dilakukan tahap berikutnya dengan melakukan pengumpulan data yang kedua. Adapun tujuan yang ditanyakan dalam kuesioner tahap II ini merupakan pertanyaan frekuensi dan dampak dari faktor-faktor keterlambatan di masing-masing tower dan podium selama proyek berlangsung mulai dari bulan oktober 2017 sampai april 2018.

Setelah semua data terkumpul, dilakukan perhitungan persiapan sebelum nantinya akan dijadikan input kedalam program add-in @RISK. Perhitungan persiapan tersebut dilakukan dalam tabel yang disebut tabel "Perhitungan Persiapan Analisis@RISK"

Tabel terdiri dari beberapa kolom dan dapat dijelaskan sebagai berikut ini :

1. Kolom 1 adalah Kolom Faktor Risiko.

Kolom ini berisi faktor-faktor risiko yang bersifat Unacceptable (tidak dapat diterima) dan Undiserable (tidak diharapkan).

2. Kolom 2 adalah Kolom Frekuensi Kejadian Selama Proyek Berlangsung. 
Kolom ini berisi frekuensi kemunculan faktor-faktor risiko selama proyek berlangsung. Satuan yang digunakan adalah jumlah kejadian selama proyek berlangsung.

3. Kolom 3 adalah Kolom Dampak Keterlambatan.

Kolom ini berisi waktu keterlambatan yang terlama (Max), waktu keterlambatan yang biasanya terjadi (most likely) dan waktu keterlambatan yang tercepat (Min). Satuan yang digunakan adalah jumlah hari keterlambatan.

4. Kolom Frekuensi

Kolom ini berisi perhitungan berupa = frekuensi kejadian salah satu faktor dibagi dengan total frekuensi kejadian.

5. Kolom Distribusi Dampak Keterlambatan

Kolom ini berisi perhitungan $=\left(\frac{M i n+\text { most likely }+ \text { Max }}{3}\right)$.

6. Kolom Distribusi x Frekuensi

Kolom ini berisi hasil perkalian kolom frekuensi dengan kolom distribusi dampak keterlambatan.

Tabel 7 Perhitungan Persiapan Analisis @RISK

\begin{tabular}{|c|c|c|c|c|c|c|}
\hline \multirow{3}{*}{ No. } & \multirow{3}{*}{ Faktor Risiko } & \multicolumn{5}{|c|}{ Distribusi x Frekuensi } \\
\hline & & \multicolumn{5}{|c|}{ SITE MANAGER } \\
\hline & & 1 & 2 & 3 & 4 & 5 \\
\hline 1 & $\begin{array}{l}\text { Ketidaktepatan waktu } \\
\text { pemesanan peralatan \& material }\end{array}$ & 0.125 & 0.0454545 & 0.37096774 & 0.20952381 & 0.33333286 \\
\hline 2 & $\begin{array}{l}\text { Kerusakan Peralatan saat } \\
\text { pekerjaan struktur }\end{array}$ & 0.0625 & 0.0606061 & 0.09677419 & 0.05714286 & 0.07738096 \\
\hline 3 & $\begin{array}{l}\text { Kekurangan Peralatan yang } \\
\text { dibutuhkan }\end{array}$ & 0.0625 & 0.0707071 & 0.09677419 & 0.12380954 & 0.13095236 \\
\hline 4 & $\begin{array}{l}\text { Pengaruh cuaca pada aktifitas } \\
\text { konstruksi. }\end{array}$ & 0.234375 & 0.1818182 & 0.1344086 & 0.28571429 & 0.26785714 \\
\hline 5 & $\begin{array}{l}\text { Masalah longsoran tanah pada } \\
\text { proses galian tanah }\end{array}$ & 0.1015625 & 0.0454545 & 0.04032258 & 0.1547619 & 0.06971248 \\
\hline 6 & $\begin{array}{l}\text { Adanya retak struktur pada } \\
\text { Retaining Wall }\end{array}$ & 0.3333331 & 0.3131313 & 0.10752688 & 0.14761906 & 0.08333321 \\
\hline 7 & $\begin{array}{l}\text { Pendetailan gambar dari Divisi } \\
\text { Engineering yang tidak sesuai } \\
\text { dengan kondisi lapangan }\end{array}$ & 0.3229167 & 0.3787879 & 0.77956989 & 0.59047619 & 0.28571429 \\
\hline 8 & $\begin{array}{l}\text { Terjadinya perubahan desain } \\
\text { dari pihak Owner }\end{array}$ & 0.6770828 & 1.0959596 & 0.79569897 & 0.22857143 & 0.53571429 \\
\hline 9 & $\begin{array}{l}\text { Terjadi perubahan jadwal \& } \\
\text { biaya rencana dari pihak Owner }\end{array}$ & 0.0729167 & 0.1212121 & 0.03763441 & 0.12380953 & 0.261905 \\
\hline 10 & $\begin{array}{l}\text { Kerusakan pada struktur kolom } \\
\text { beton. }\end{array}$ & 0.296875 & 0.3939394 & 0.27956989 & 0.55238091 & 0.41666071 \\
\hline & TOTAL & 2.2890618 & 2.7070707 & 2.73924735 & 2.47380951 & 2.4625633 \\
\hline
\end{tabular}


Berikut ini adalah langkah-langkah menjalankan simulasi @RISK untuk menghasilkan grafik barchart Regression Mapped Value dari masing-masing site manager :

1. Menentukan Fitiing Distribution di kolom Distribusi Dampak Keterlambatandengan mengklik Define Distributions di toolbar @RISK

2. Pilih distribusi data yang digunakan, dalam penelitian ini penulis menggunakan distribusi triangular karena menggunakan sedikit sampel dan terbatas. Distribusi ini menggunakan input data berupa Min, Most Likely dan Max. Selanjutnya adalah menginput data minimum, most likely, dan maximum pada @ RISK.

3. Untuk memperoleh Risk Output, dilakukan dengan mengklik Add Output pada toolbar @RISK dan memasukkan nama cell yang ingin diproses.Apabila tidak menentukan Risk Output pada salah satu cell yang ingin diproses, maka simulasi tidak bisa berjalan.

4. Setelah menentukan Fitting Distributions dan Risk Output, tentukan simulasi akan dijalankan sebanyak berapa kali, kemudian klik start dan simulasi yang sudah selesai diproses menghasilkan output berupa nilai total distribusi $\mathrm{x}$ frekuensi.

5. Terakhir adalah memunculkan grafik barchart regression mapped value dengan mengklik menu TornadoRegression mapped values $\stackrel{\bar{F}}{\longrightarrow}$ pada lembar kerja.

\subsection{Analisis Peringkat Risiko Kritis diantara Kelima Site Manager}

Berikut ini adalah perbandingan peringkat faktor risiko yang didapat dari hasil output program @ RISK pada kelima site manager bekerja di proyek konstruksi superblock ASC.

Tabel 5 Perbandingan peringkat faktor risiko dari masing-masing site manager

\begin{tabular}{|c|c|c|c|c|c|}
\hline \multicolumn{6}{|c|}{ Peringkat Faktor Risiko dari masing-masing Site Manager } \\
\hline Faktor Risiko & $\begin{array}{c}\text { Site } \\
\text { Manager } \\
1 \\
\end{array}$ & $\begin{array}{c}\text { Site } \\
\text { Manager } \\
2 \\
\end{array}$ & $\begin{array}{c}\text { Site } \\
\text { Manager } \\
3 \\
\end{array}$ & $\begin{array}{c}\text { Site } \\
\text { Manager } \\
4 \\
\end{array}$ & $\begin{array}{c}\text { Site } \\
\text { Manager } \\
5 \\
\end{array}$ \\
\hline $\begin{array}{l}\text { Terjadi Perubahan Desain } \\
\text { dari pihak owner }\end{array}$ & 1 & 1 & 1 & 4 & 1 \\
\hline $\begin{array}{l}\text { Pendetailan gambar dari } \\
\text { Divisi Engineering yang } \\
\text { tidak sesuai kondisi lapangan }\end{array}$ & 2 & 3 & 2 & 1 & 5 \\
\hline $\begin{array}{c}\text { Adanya retak struktur pada } \\
\text { Retaining Wall }\end{array}$ & 3 & 6 & 9 & 10 & 9 \\
\hline $\begin{array}{c}\text { Pengaruh Cuaca pada } \\
\text { aktifitas konstruksi }\end{array}$ & 4 & 4 & 3 & 2 & 3 \\
\hline $\begin{array}{c}\text { Kerusakan pada struktur } \\
\text { kolom beton }\end{array}$ & 6 & 2 & 5 & 3 & 2 \\
\hline $\begin{array}{c}\text { Ketidaktepatan waktu } \\
\text { pemesanan peralatan } \& \\
\text { material }\end{array}$ & 5 & 5 & 4 & 8 & 4 \\
\hline $\begin{array}{c}\text { Kerusakan Peralatan saat } \\
\text { dibutuhkan }\end{array}$ & 7 & 8 & 8 & 7 & 8 \\
\hline $\begin{array}{c}\text { Terjadi perubahan jadwal \& } \\
\text { biaya rencana dari pihak } \\
\text { owner }\end{array}$ & 8 & 7 & 7 & 9 & 6 \\
\hline $\begin{array}{c}\text { Masalah Longsoran saat } \\
\text { galian tanah }\end{array}$ & 9 & 10 & 10 & 5 & 10 \\
\hline $\begin{array}{l}\text { Kekurangan peralatan yang } \\
\text { dibutuhkan }\end{array}$ & 10 & 9 & 6 & 6 & 7 \\
\hline
\end{tabular}


Setelah mendapatkan hasil output dari program add-in @RISK tersebut, dapat dilihat bahwa faktor-faktor dominan berbeda antara site manager yang satu dengan site manager lainnya. Oleh sebab itu dilakukanlah interview/wawancara tahap selanjutnya untuk melakukan validasi terhadap hasil-hasil output @RISK tersebut. Interview dilakukan terhadap para site manager kembali dengan issue issue yang lebih mendetail akan permasalahan yang terjadi. Berikut adalah hasil analisis dan penjelasan yang diperoleh.

\section{a) Perubahan Desain dari Pihak Owner}

Perubahan desain di tower 1, 2, 3 dan podium zona 6 \& 7 ini memiliki dampak yang besar daripada perubahan desain di podium zona $4 \& 5$. Perubahan desain di tower 1, 2, 3 ini disebabkan oleh perubahan luas kamar dari $36 \mathrm{~m}^{2}$ menjadi $56 \mathrm{~m}^{2}$. Di podium zona $6 \& 7$, perubahan desain dilakukan terhadap ramp parkir basement. Di podium zona $4 \& 5$, perubahan desain hanya dilakukan pada penambahan atap dak beton di atas lantai P4.

\section{b) Pendetailan Gambar dari Divisi Engineering yang Tidak Sesuai Kondisi Lapangan}

Pendetailan gambar di podium zona 4 \& 5 (site manager 4) memiliki dampak yang besar daripada podium zona $6 \& 7$ (site manager 5 ). Di podium zona $4 \& 5$, detail gambar balok induk menyebabkan adanya perbedaan elevasi antara balok di podium dengan elevasi balok di tower. Pada podium zona 6 \& 7, kesalahan pendetailan gambar tulangan balok ramp parkir di podium zona 6B lantai $\mathrm{P} 2$ disebabkan oleh perbedaan elevasi antara balok ramp dengan kolom tower walaupun tidak berbeda jauh.

c) Adanya Retak Struktur pada Retaining Wall

Faktor risiko adanya retak struktur pada Retaining Wall dari site manager 1 dan 2 menempati peringkat 3 \& 6 sedangkan site manager 3, 4 dan 5 yang menempati peringkat 9 dan 10. Retak yang terjadi pada retaining wall di basement 1 merupakan retak struktur yang cukup besar dan dominan. Kerusakan struktur retaining wall di tower 1 ini membutuhkan proses perbaikan dan pemeriksaan berkala selama 7 hari

d) Pengaruh Cuaca pada Aktifitas Konstruksi

Faktor risiko pengaruh cuaca terhadap aktifitas konstruksi pada seluruh site manager yang ada tidaklah berbeda jauh. Hal ini memang terjadi karena pembangunan tower dan podium dilakukan bersamaan. Adapun masalah yang timbul saat konstruksi pada podium zona $4 \& 5$ (site manager 4 ) adalah hanya 2 unit pompa air yang berfungsi dari total 6 unit pompa yang tersedia saat itu.

e) Kerusakan pada Struktur Kolom Beton

Ketidakhati-hatian dalam melakukan pekerjaan pengecoran beton mengakibatkan kerusakan struktur yang cukup signifikan pada kolom beton tersebut. Hal ini terjadi pada kolom di tower 2, podium zona 4 \& zona 5, dan podium zona 6 \& 7. Beberapa pekerja harus ditarik dari pekerjaan struktur diatasnya untuk melakukan perbaikan kolom-kolom ini. Hal ini mengakibatkan terganggunya pekerjaan struktur diatasnya yang berdampak selama 2 hari.

f) Ketidaktepatan Waktu Pemesanan Peralatan \& Material

Ketidaktepatan waktu pemesanan peralatan dan material merupakan faktor risiko yang cukup berperan dalam keterlambatan proyek yang terjadi di tower 1 (site manager 1), tower 2 (site manager 2), tower 3 (site manager 3), dan podium zona 6 \& zona 7 (site manager 5). Hal yang menyebabkan faktor ini menjadi berperan adalah dikarenakan akibat dampak dari perubahan desain kamar apartemen dari seluas $36 \mathrm{~m} 2$ menjadi $56 \mathrm{~m} 2$.

g) Kerusakan Peralatan saat Dibutuhkan

Faktor risiko kerusakan peralatan saat dibutuhkan pada seluruh site manager yang ada tidaklah berbeda jauh. Hal ini memang terjadi karena terjadi kerusakan beberapa kali pada 6 tower crane di proyek ASC ini.

h) Terjadi Perubahan Jadwal \& Biaya Rencana dari Pihak Owner

Faktor risiko perubahan jadwal \& biaya rencana dari pihak owner dalam proyek ini berada pada posisi risiko menengah (untuk site manager 1, 2, 3 dan 5) sampai dengan risiko rendah (untuk site manager 4). Pada tower 1, 2 dan 3, perubahan desain kamar apartemen dari $36 \mathrm{~m} 2$ menjadi $56 \mathrm{~m} 2$. Untuk podium zona 4 \& zona 5 (site manager 4 ), perubahan desain hanya dilakukan pada penambahan atap dak beton di lantai P4. Pada podium zona $6 \& 7$ (site manager 5) harus dilakukan perubahan desain ramp parkir

i) Masalah Longsoran saat Galian Tanah

Faktor masalah longsoran terparah adalah yang terjadi pada podium zona 4 \& zona 5 (site manager 4 ). Masalah longsoran yang parah pada podium zona 4 \& zona 5 ini (site manager 4) terjadi karena jumlah dolken kayu yang terbatas dan kerusakan pada unit excavatoryang menyebabkan terjadinya penundaan pemasangan dinding penahan tanah selama 2 hari. 
j) Kekurangan Peralatan yang Dibutuhkan

Faktor risiko kekurangan peralatan dari site manager 3, 4 dan 5 merupakan risiko menengah (middle risk) sedangkan site manager 1 dan 2 menempati risiko yang kecil. Pada tower 1 (site manager 1) dan tower 2 (site manager 2), terjadi kekurangan concrete pump. Pada tower 3 dan podium zona 6 \& 7 , kekurangan peralatan berupa concrete pump dan concrete vibrator.

\section{KESIMPULAN}

Dari hasil analisis yang telah dilakukan terhadap output program add-in @RISK, dapat disimpulkan sebagai berikut ini :

1) Faktor- faktor risiko penyebab keterlambatan yang dominan terjadi \&sudah dilakukan proses klasifikasi risiko adalah sebagai berikut ini :

a) Dua faktor risiko penyebab keterlambatan yang bersifat Unacceptable (tidak dapat diterima).

b) Delapan faktor risiko penyebab keterlambatan yang bersifat Undiserable ( tidak diharapkan)

2) Terdapat 5 faktor risiko terbesar yang berpengaruh terhadap keterlambatan pada proyek konstruksi ASC ini antara lain :

a) Perubahan desain dari pihak owner

b) Pendetailan gambar yang tidak sesuai kondisi lapangan

c) Pengaruh cuaca

d) Kerusakan struktur bangunan

e) Ketersediaan peralatan dan material yang dibutuhkan

3) Perubahan desain dari pihak owner dapat menimbulkan dampak lanjutan yang juga dapat mempengaruhi keterlambatan lanjutan dari faktor risiko lainnya.

4) Faktor pendetailan gambar, kerusakan struktur bangunan, kerusakan peralatan dan ketersediaan peralatan \& material merupakan faktor managemen dari pihak kontraktor.

\section{DAFTAR PUSTAKA}

Anonim. 2004. Risk Analysis and Simulation Add-In for Microsoft Excel version 4.5, Newfield, NY USA14867 : Palisade Corporation

Ariyani, D. 2013. Risk Assesment Dengan Simulasi Monte Carlo dan Mitigasinya Pada Industri Compressed Natural Gas. Institut Teknologi Sepuluh Nopember Surabaya

Asiyanto. 2008. Metode Konstruksi GedungBertingkat. Penerbit Universitas Indonesia,Jakarta.

Chan, D. and Kumaraswamy, M. 2002. A comparative study of causes of time overrun in Hong Kong construction projects. International Journal of Construction Management

Enshassi, I. 2003. Significant Factors Causing Time and Cost Overruns in Construction Projects in the Gaza Strip: Contractors' Perspective. International Journal of Construction Management

Godfrey, P. 1996. Control of Risk: A Guide to the Systematic Management of Risk from Construction, Construction Industry Research and Information Association, London

Hallikas, J. 2004. Risk management processes in supplier networks. International Journal of Production Economics, Volume 90, Pages 47-58

Hoffman, O. \& Hammonds, J. 1994. Propagation of Uncertainty in Risk Assessments: The Need to Distinguish Between Uncertainty Due to Lack of Knowledge and Uncertainty Due to Variability. https://www.researchgate.net/publication/15398068 (diakses pada tanggal 16 Juli 2018)

Kaming, 1997. Factors influencing construction time and cost overruns on high-rise projects

in Indonesia, Construction Management and Economics. International Journal of Construction Management

Kwak, Y. H., \& Ingall, L. 2007.Exploring Monte Carlo Simulation Applications For Project Management. Risk Management, 9, 44-57

Mills, Anthony. 2001. A Systematic Approach to Risk Managament for Construction, Melbourne, Victoria Australia PMI. (2013). A Guide to The Project Managament Body of Knowledge (PMBOK Guide) $5^{\text {th }}$ edition. Newton Square, Pennsylvania: Project Management Institute.Inc. 
Raftery, J. 2003. Risk Analysis in Project Management 1st edition. Routledge, London : Taylor \& Francis Soeharto, I. 2001. Manajemen Proyek dari Konseptual sampai Operasional. Jakarta: Erlangga.

Soemarno, 2008. Manajemen ResikoProyek Kontruksi, Resiko dan Analisisnya. Jakarta : Erlangga Vilko, J. 2011. Risk management in the Gulf of Finland cargo flows. Lappeenranta University of Technology

Widawati, E. N. 2011. Risiko Kegagalan Bangunan dari Aspek Manajemen Proyek Konstruksi. Universitas Indonesia 